\title{
PRENATAL DEVELOPMENT OF HUMAN CALCAN- EUS AND THE ROLE OF CARTILAGE CANALS IN OSSIFICATION PROCESS: HISTOLOGICAL STUDY
}

\author{
$\mathscr{B} y$ \\ Amal M. Moustafa* and Amany M. Shams
}

Trom

Departments of Histology \& Cell Biology* and Anatomy

\& Embryology, Faculty of Medicine, Mansoura University

\begin{abstract}
Background : the calcaneus clear-

ly demonstrates the characteristics

of ossification processes that are found in both short and long bones.

Cartilage canals are found in the epiphysis of long bones and in small and irregular bones, but their role in ossification process have not been established.
\end{abstract}

Aim of the work : to study the developing calcaneus and to clarify the role of cartilage canals in the boneforming process.

Materials and Methods : Twenty four human fetuses were used in this study in $9^{\text {th }}, 10^{\text {th }}, 13^{\text {th }}, 15^{\text {th }}, 17^{\text {th }}$, $19^{\text {th }}, 22^{\text {nd }}$ and $24^{\text {th }}$ weeks of gestation. Sagittal sections were prepared

87 from the calcaneus and stained with haematoxylin \& Eosin, alcian blue \& periodic acid Schiff reagent and Mallory stains.

Results : In $9^{\text {th }}$ week-aged fetus, the calcaneus showed undifferentiating cells with no cartilage canals. In $10^{\text {th }}$ week-aged fetus, the cartilage canals began to originate from the perichondrium. In $13^{\text {th }}$ week-aged fetus, there was an area of proliferated cartilage cells which were arranged in groups. The cartilage canals comprised connective tissue, blood vessels and were surrounded by collagen fibers and exhibited +ve PAS reaction. In $15^{\text {th }}$ week-aged fetus, there was hypertrophied chondrocytes arranged in small groups. In $17^{\text {th }}$ week-aged fetus the hypertrophied MANSOURA MEDICAL JOURNAL 


\section{PRENATAL DEVELOPMENT OF HUMAN CALCANEUS etc...}

cartilage cells in the center of the calcaneus were arranged in pairs or small groups surrounded by expanded areas of pale basophilic matrix. In $19^{\text {th }}$ week-aged fetus the perichondral ossification center appeared. In $22^{\text {nd }}$ week-aged fetus the endochondral center of ossification appeared in the form of ossified matrix around cartilage canal with marrow spaces. Increased patches of basophilic matrix around hypertrophied chondrocytes were seen. In $24^{\text {th }}$ week-aged fetus the perichondral center and the endochondral center of ossification became more developed. The primary center of ossification showed large areas of bone formation in the form of specules or trabeculation separated by areas of marrow spaces filled with blood cells. The cartilage canals showed significant progressive increase in both number and size. Cartilage canals showed thin discontinuous wall at more advanced ages of gestation.

Conclusion : Cartilage canals are involved in the nourishment of the cartilage cells as well as in the ossification process. Calcanean endochondral ossification center was detectable at $22^{\text {nd }}, 24$ th weeks of gestation so, it is recommended to be used as a mean to evaluate gestational age in late pregnancy by ultrasonography.

Key words : Calcaneus, Prenatal development, Cartilage canals, Human Fetus.

\section{INTRODUCTION}

The calcaneus is the largest tarsal bone in the foot and is well designed to sustain high tensile, bending, and compressive forces [Hall and Shereff, 1993] ${ }^{17}$. Congenital deformities of the calcaneus is one of causes that result in congenital clubfoot, which precludes normal gait [Walling, 2008].32 Many theories have been proposed to explain the etiology of congenital idiopathic clubfoot including vascular deficiencies due to deficiency or absence of the anterior tibial artery [Hootnick et al., 1982]. ${ }^{20}$

The calcaneus clearly demonstrates the characteristics of ossification processes that are found in both short and long bones. The ossification process in the normal calcaneus is a precise sequence of perichondral and endochondral ossification [Fritsch and Eggers, 1999]. ${ }^{13}$

Endochondral ossification is the 
process by which the embryonic cartilaginous model of most bones is gradually replaced by bone [Mackie et al., 2008]. ${ }^{24}$ An essential event for the development of the endochondral ossification centre is the early generation of the vascularized cartilage canals that requires the proteolytic cleavage of the cartilaginous matrix [Blumer et al., 2008B]. ${ }^{7}$ In addition, the avascular cartilaginous anlage is invaded by numerous blood vessels, through the process of angiogenesis [Doschak et al., 2003]. ${ }^{10}$

Cartilage canals are found in the epiphysis of long bones and in cartilaginous anlage of small and irregular bones prior to the formation of a secondary ossification centre (SOC). Their exact role is still controversial and it is unclear whether they contribute to endochondral bone formation when secondary ossification centre (SOC) appears or not [Blumer et al., 2005]. 8 The structure of vascular cartilage canals is important for a more thorough understanding of the development of cartilage and the growth plate in the human neonate and growing child [Gruber et al., 1990]. ${ }^{16}$
Therefore, the present study was designed to study the developing fetal human calcaneus and to clarify the role of cartilage canals in the bone-forming process.

\section{MATERIAL AND METHODS}

Twenty four human fetuses in 9th, 10 th, $13^{\text {th }}, 15^{\text {th }}, 17^{\text {th }}, 19^{\text {th }}, 22^{\text {nd }}$ and $24^{\text {th }}$ weeks of gestation (3 fetuses for each age) were used in this study. All fetuses were cases of legal abortion or miscarriage with no signs of maceration or macroscopic abnormalities. They were obtained after agreement of Gynecology and Obstetrics Department, Mansoura University Hospital. Fetal age was determined by exact measurement of crown-rump (CR) lengths [Moore, 1982]. 27

The two feet of each fetus were dissected to obtain the calcanei. They were fixed in $10 \%$ formaldehyde. Decalcification was done in older fetuses by using $25 \%$ ethylenediamine tetra acetic acid (EDTA pH 7.4) for 2 weeks. Then the specimens were dehydrated, cleared and embedded in paraffin. Sagittal sections at 6 um were cut and stained alternately with haematoxylin \& eosin stain $(H \& E)$, alcian blue \& peri-

MANSOURA MEDICAL JOURNAL 
90 PRENATAL DEVELOPMENT OF HUMAN CALCANEUS etc...

odic acid schiff stains (AB/PAS) and fibrous layer of perichondrium and Mallory stain [Bancroft and Gamble, revealed clumps of undifferentiated 2008]. ${ }^{3}$

\section{STATISTICAL ANALYSIS}

Sagittal sections of six calcanei, in each group, were examined and the number \& diameter of cartilage canals of the calcaneus were measured by using the ocular-leitzfilar micrometer eye piece for light microscope at a magnification $\times 100$. Measurements at 10 weeks age group were considered basal group as measurements at 9 weeks age group were non valid as their values were zero.

The histological data were analyzed using the statistical package SPSS version 10. Data were expressed as mean \pm standard deviation (SD). The statistical significance of differences between groups was analyzed using the one-way analysis of variance (ANOVA) followed by post hoc test of Tukey HSD. $P$ value of $<0.05$ was considered significant.

\section{RESULTS \\ In $9^{\text {th }}$ week-aged fetal calcaneus}

Light microscopic study of $\mathrm{H}$ \& $\mathrm{E}$ stained sections showed that the calcaneus was covered from outside by cells with mitotic figures. There is no evident cartilage canals (Figs. 1, 2).

In $10^{\text {th }}$ week-aged fetal calcaneus

The perichondrium appeared thick. The cartilage canals originated from the perichondrium and invaded the calcaneus giving many side sprouts inside the calcaneus (Fig. 3). The early-developing cartilage canals contained multiple small blood vessels and mesenchymal C.T. The calcaneus showed undifferentiated cells (Fig. 4).

\section{In $13^{\text {th }}$ week - aged fetal calcaneus}

The H \& E stained sections of calcaneus showed increased number and size of cartilage canals and the cartilage canals contained numerous blood vessels and abundant mesenchymal connective tissue (CT) (Fig. 5). The cells around the cartilage canals appeared differentiated into large rounded chondrocytes with open-face nuclei and pale basophilic cytoplasm and were embedded in lacunae. Two divided cells in a single lacuna "cell nests" were also seen (Fig. 6).

Alcian blue and periodic acid

Vol. 42, No. 1 \& 2 Jan. \& April, 2013 
Schiff stained (AB/PAS) sections of calcaneus demonstrated PAS positive reaction in the cytoplasm of the chondrocytes, undifferentiated cells, CT of the cartilage canal and mesenchymal CT cells. The matrix showed AB/PAS positive reaction (Fig. 7).

Mallory's stained sections of calcaneus showed blue stained collagenous fibers in the perichondrium and wall of the cartilage canals. In addition, pale blue stained collagenous fibers were seen in the matrix between the proliferating chondrocytes and mesenchymal CT inside the cartilage canal (Fig. 8).

\section{In $15^{\text {th }}$ week-aged fetal calcaneus}

In $\mathrm{H}$ \& $\mathrm{E}$ stained sections of calcaneus, most of the cells were differentiated into chondrocytes with appearance of cell nests. The cartilage canals became large in size with multiple blood vessels (Fig. 9).

The calcanean sections showed a strong PAS positive reaction in the cytoplasm of chondrocytes, thick wall of the cartilage canals, matrix around the canals and mesenchymal CT around the blood vessels. The matrix between the proliferating chondrocytes exhibited AB/PAS pos- itive reaction (Fig. 10).

Mallory's stained sections of calcaneus showed blue stained collagenous fibers in the wall of the cartilage canals, matrix around the canals and mesenchymal CT around the blood vessels. Fine blue stained collagenous fibers were seen in the matrix between the proliferating chondrocytes (Fig. 11).

\section{In $17^{\text {th }}$ week-aged fetal calcaneus}

In $\mathrm{H}$ \& $\mathrm{E}$ stained sections of calcaneus, the central part of the calcaneus showed proliferating chondrocytes that were arranged in pairs or small groups and hypertrophied chondrocytes separated by abundant matrix. The cartilage canals showed little content and were concentrically arranged around the central part of the calcaneus (Fig. 12).

The sections of calcaneus showed PAS positive reaction in the matrix, wall and mesenchymal CT content of the cartilage canals (Fig. 13).

Mallory's stained sections of calcaneus showed blue stained collagenous fibers in the wall of the cartilage canals and the matrix (Fig. 14). 


\section{PRENATAL DEVELOPMENT OF HUMAN CALCANEUS etc...}

\section{In $19^{\text {th }}$ week-aged fetal calcaneus}

$H$ \& $E$ stained sections demonstrated the appearance of irregular perichondral plates enclosing multiple canals in the perichondrium. The perichondral plates contained osteocytes embedded in matrix and osteoblasts on the peripheral borders. The canals contained blood vessels and abundant CT. In addition, the majority of the calcanean cells, beneath the perichondrium, appear differentiated into chondrocytes (Fig. 15). The central part of the developing calcaneus exhibited different concentric zones as; resting chondrocytes, proliferating chondrocytes that were arranged in pairs or small groups, hypertrophied chondrocytes separated by calcified matrix (stage of calcification). Some channels were invaded by mesenchymal tissue (Fig. 16).

The sections of calcaneus displayed a strong PAS positive reaction in certain parts of the wall of the cartilage canals and the other parts appeared interrupted. The matrix exhibited AB/PAS positive reaction (Fig. 17).

Mallory's stained sections of calcaneus showed blue stained collage- nous fibers in the matrix of the perichondral plates and wall of the cartilage canals. In addition, pale blue stained collagenous fibers were demonstrated in the matrix of the calcaneus (Fig. 18).

\section{In $2^{\text {nd }}$ week-aged fetal calcaneus}

The sections showed the developing endochondral ossification center at the central part of the developing calcaneus. It was surrounded by different zones; resting chondrocytes, proliferating chondrocytes that were arranged in pairs or small groups, hypertrophied chondrocytes and hypertrophied chondrocytes separated by calcified matrix. The majority of the calcified channels became invaded by mesenchymal tissue (stage of invasion). The cartilage canals were concentrically arranged around the endochondral ossification center (Fig. 19).

A strong PAS positive reaction was found in the thick wall of the cartilage canals around the endochondral ossification center and in their little CT contents (Fig. 20).

Mallory's stained sections of calcaneus showed blue stained collagenous fibers in the perichondrium, 
wall of the cartilage canals, little content of the cartilage canals and calcified matrix. The matrix between the chondrocytes stained pale blue. The large cartilage canal near the endochondral ossification center exhibited interrupted wall and loss of content. Some cartilage canals between the hypertrophied chondrocytes exhibited interrupted wall with passage of their cellular content to the surrounding channels. Other cartilage canals appeared incorporated in the endochondral ossification center with thin interrupted wall and communicated with the surrounding channels (Figs. $21,22 A, B)$.

\section{In $2^{\text {th }}$ week-aged fetal calcaneus}

The $H$ \& $E$ stained sections showed regular perichondral plates around the calcaneus enclosing cartilage canals. Most of the cells under the perichondrium were differentiated into mature chondrocytes and were separated by abundant matrix (Fig. 23). Multiple bony spicules (trabeculae) separated by multiple bone marrow spaces were demonstrated in the developing endochondral ossification center. Cartilage canals with little content were seen incorporated at the ossification center (Fig. 24).
The perichondral plates revealed a strong PAS positive reaction in the matrix, cytoplasm of osteocytes and in connective tissue around the cartilage canal blood vessels (Fig. 25). PAS positive reaction was also demonstrated in the newly formed bony spicules around the calcified matrix, cytoplasm of the bone marrow cells and thin discontinuous wall of cartilage canals which opened into the surrounding hypertrophied chondrocytes. The cartilage matrix exhibited AB/PAS positive reaction, while the calcified matrix was stained with alcian blue (Figs. 26, 27, 28).

Blue stained collagenous fibers were detected in the perichondral plates (Fig. 29), calcified matrix and thin interrupted wall of the cartilage canal which opened into the surrounding hypertrophied chondrocytes. The bone marrow cells stained red. In addition, osteocytes were observed embedded in the newly formed bony spicules (Fig. 30).

\section{STATISTICAL RESULTS}

The present study recorded a highly significant increase $(P \leq 0.01)$ in the mean number (table-1 \& Histogram-1) and diameter (table-2\& Histogram-2) of cartilage canals with in-

MANSOURA MEDICAL JOURNAL 
94 PRENATAL DEVELOPMENT OF HUMAN CALCANEUS etc...

creased fetal age. However a non significant increase $(P>0.05)$ in the significant increase $(P>0.05)$ in the mean diameter of cartilage canals mean number of cartilage canals (table-2\& Histogram-2) was recorded was recorded in 19 and 22 weeks aged fetal calcaneus compared to 17 weeks old group (table-1 \& Histogram-1). On the other hand a non in 17 and 19 weeks aged fetal calcaneus compared to 15 weeks old group (table-2\& Histogram-2).

Table (1): The mean number + SD of cartilage canals of human fetal calcaneus per high power field in different age groups and their significance (p).

\begin{tabular}{|c|c|c|}
\hline & $\begin{array}{c}\text { Mean number } \\
\pm \text { SD }\end{array}$ & significance (P) \\
\hline 9 wks & 0.00 & \\
\hline $10 \mathrm{wks}$ & $2.66 \pm 0.61$ & $.000^{* *}$ \\
\hline $13 \mathrm{wks}$ & $6.20 \pm 1.01$ & $.000^{* *}$ \\
\hline $15 \mathrm{wks}$ & $15.47 \pm 4.68$ & $.000^{* *}$ \\
\hline $17 \mathrm{wks}$ & $22.13 \pm 2.99$ & .403 \\
\hline $19 \mathrm{wks}$ & $22.80 \pm 2.80$ & .414 \\
\hline $22 \mathrm{wks}$ & $23.80 \pm 4.52$ & $.000^{* *}$ \\
\hline $24 \mathrm{wks}$ & $60.53 \pm 16.91$ & \\
\hline
\end{tabular}

One way ANOVA; * $\mathrm{p}<0.05$ significant.

$\mathrm{P}>0.05$ Non significant, $* \mathrm{p} \leq 0.05$ Significant, $* * \mathrm{P} \leq 0.01$ Highly significant

Table (2): The mean diameter + SD of cartilage canals of human fetal calcaneus per high power field in different age groups and their significance $(p)$.

\begin{tabular}{|c|c|c|}
\hline & $\begin{array}{c}\text { Mean diameter } \pm \\
\text { SD }\end{array}$ & significance (P) \\
\hline $9 w \mathrm{ws}$ & 0.00 & \\
\hline $10 \mathrm{wks}$ & $41.06 \pm 9.72 \mu \mathrm{m}$ & \\
\hline $13 \mathrm{wks}$ & $69.66 \pm 28.09 \mu \mathrm{m}$ & $.004^{* *}$ \\
\hline $15 \mathrm{wks}$ & $104.86 \pm 41.75 \mu \mathrm{m}$ & $.013^{*}$ \\
\hline $17 \mathrm{wks}$ & $125.40 \pm 28.74 \mu \mathrm{m}$ & .142 \\
\hline $19 \mathrm{wks}$ & $142.26 \pm 50.14 \mu \mathrm{m}$ & .340 \\
\hline $22 \mathrm{wks}$ & $240.53 \pm 83.75 \mu \mathrm{m}$ & $.000^{* *}$ \\
\hline $24 \mathrm{wks}$ & $443.66 \pm 161.01 \mu \mathrm{m}$ & $.001^{* *}$ \\
\hline
\end{tabular}

One way ANOVA; *p<0.05 significant.

$\mathrm{P}>0.05$ Non significant, ${ }^{*} \mathrm{p} \leq 0.05$ Significant, $* * \mathrm{P} \leq 0.01$ Highly significant

Vol. 42, No. 1 \& 2 Jan. \& April, 2013 


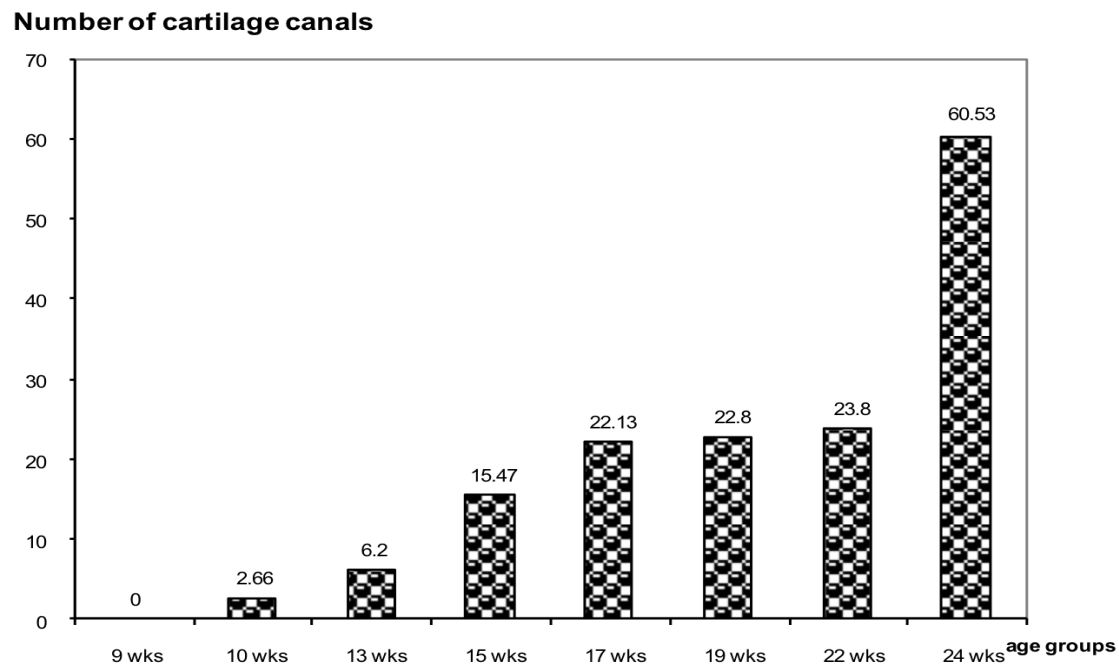

Histogram (1): Shows the mean number of cartilage canals of human fetal calcaneus in different age groups.

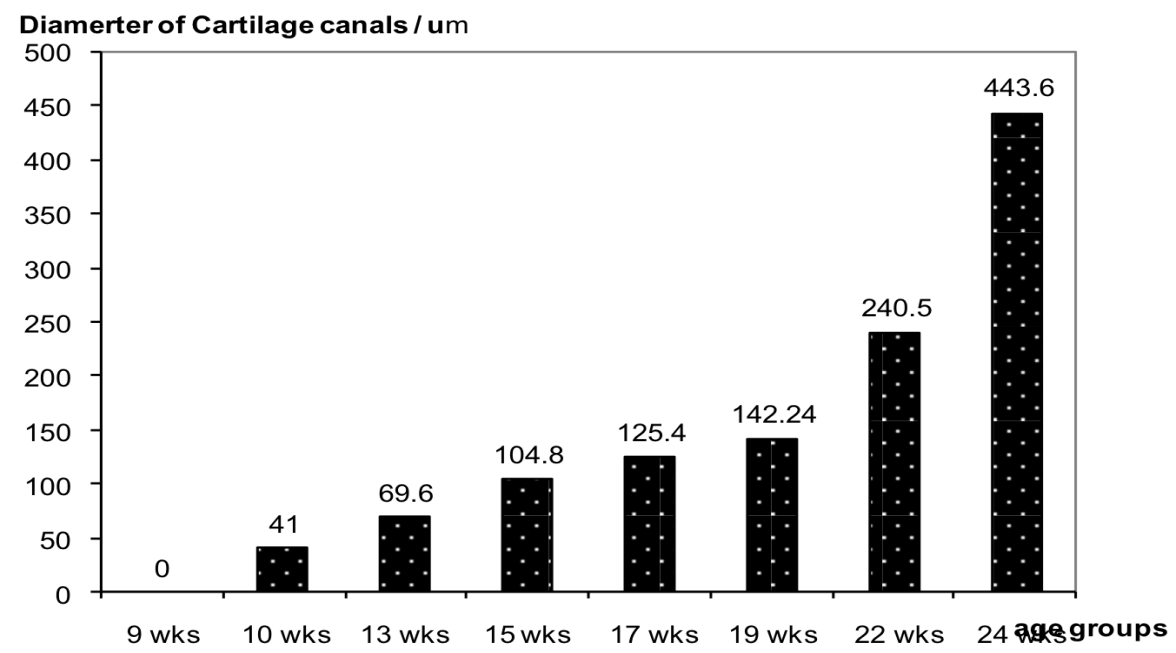

Histogram (2): Shows the mean diameter of cartilage canals of human fetal calcaneus in different age groups.

MANSOURA MEDICAL JOURNAL 
96 PRENATAL DEVELOPMENT OF HUMAN CALCANEUS etc...

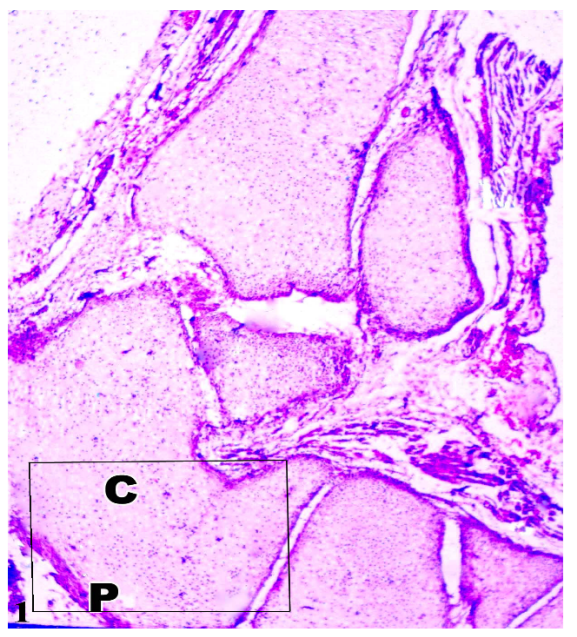

Fig. (1): A photomicrograph of a section in human fetal calcaneus aged 9 weeks showing the developing calcaneus (C) surrounded from outside by perichondrium $(P)$. (H\& E x40).

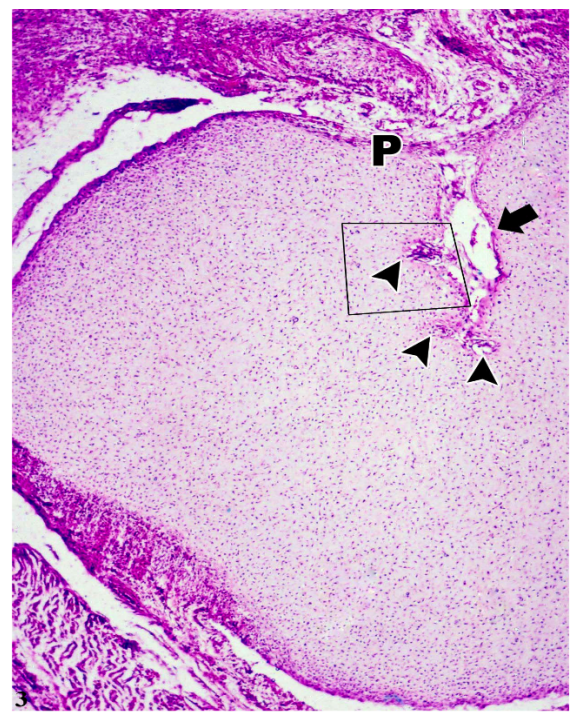

Fig. (3): A photomicrograph of a section in human fetal calcaneus aged 10 weeks showing a cartilage canal thick arrow) originating from the perichondrium (p), invading the calcaneus and giving many sides sprouts (arrow heads). (H\& E X 40)

Vol. 42, No. 1 \& 2 Jan. \& April, 2013

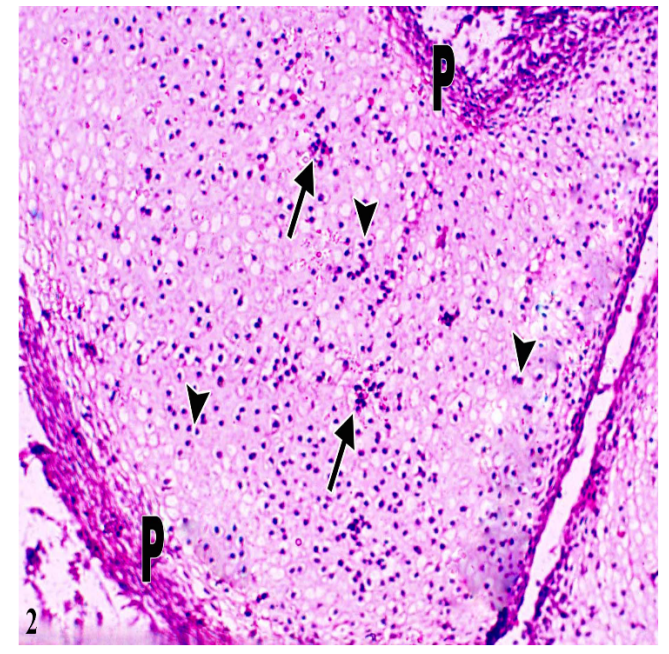

Fig. (2): A high power magnification of the inset in (Fig. 1) showing the calcaneus chondrium $(P)$. It contains clumps of chondifium (P)entiated cells (arrows). Some cells show mitotic figures (arrow heads). (H\& E x100)

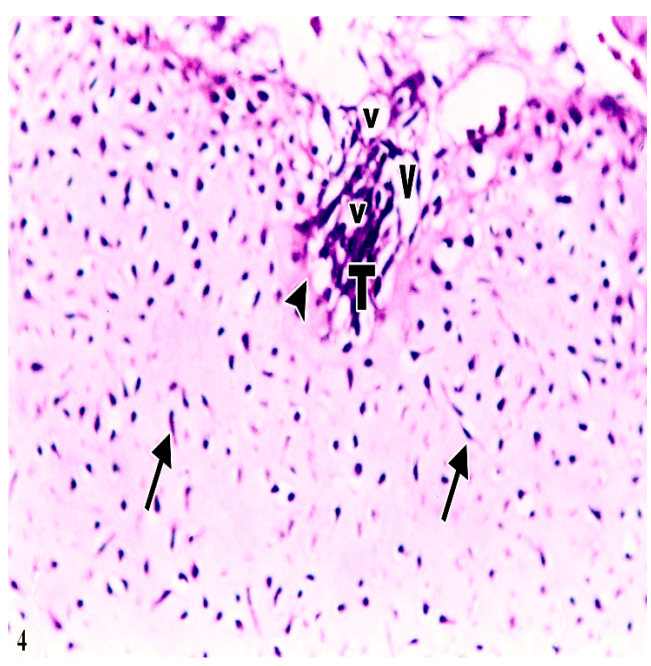

Fig. (4): A high power magnification of the inset in (Fig.3) showing a small early-developing cartilage canal (arrow head) containing multiple small blood vessels (V) and mesmanchymal connective tissue (T) The calcaneus shows undifferentiated cells (arrows). (H\& E x100) 


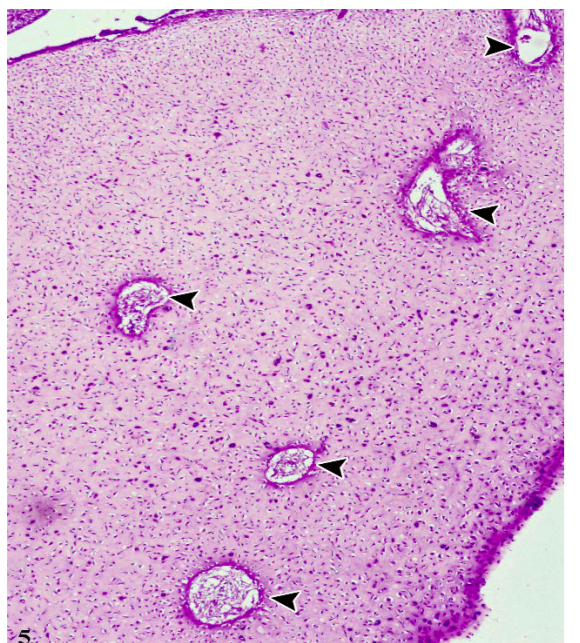

Fig. (5): A photomicrograph of a section in human fetal calcaneus aged 13 weeks showing increased number and size of cartilage canals (arrow heads). (H\& E x 40)

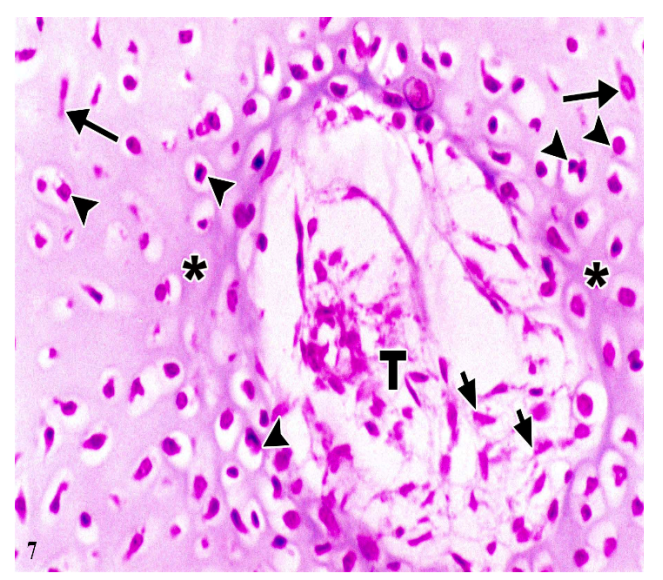

Fig. (7) : A photomicrograph of a section in human fetal calcaneus aged 13 weeks showing PAS positive reaction in the cytoplasm of the chondrocytes (arrow heads), undifferentiated cells (arrows), mesenchymal CT (T) of the cartilage canal and CT cells (short arrows). The matrix shows AB/PAS positive reaction (asterisks). (AB/PAS reaction X 400)

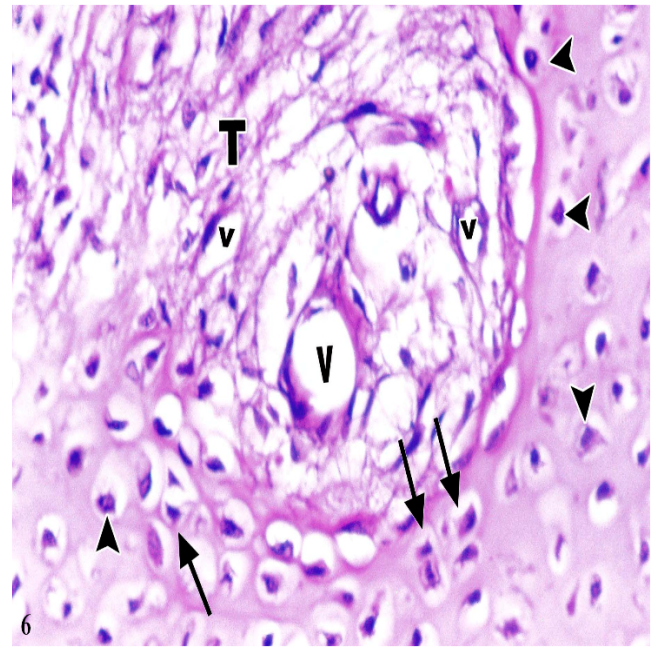

Fig. (6) : A photomicrograph of a section in human fetal calcaneus aged 13 weeks showing the cartilage canal containing numerous blood vessels (V) and abundant connective tissue (T). The entiated into large rounded chondrocytes embedded in lacunae (arrow heads) and have open-face nuclei and pale basophilic cytoplasm. Cell nests (arrows) are also seen (H\&
p 400 )

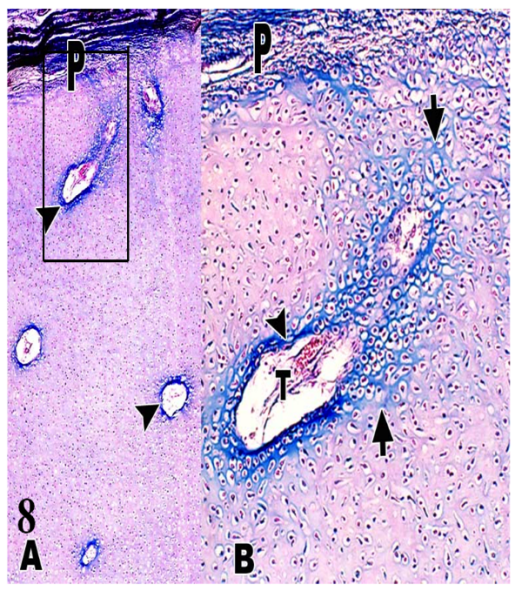

Fig. (8): Two photomicrographs of sections in human

(A) : showing blue stained collagenous fibers in the perichondrium ( $P$ ) and wall of the cartilaO) (B): showing high power magnification of the inset in (A) showing blue stained collagenous fibers in the perichondrium $(P)$ and wall of the cartilage canals (arrow heads). Note pale blue stained collagenous fibers in the matrix (short arrows) between the proliferating chondrocytes and $C T$ (T) inside the cartilage canal. (Mallory's stain $x$

MANSOURA MEDICAL JOURNAL 
98 PRENATAL DEVELOPMENT OF HUMAN CALCANEUS etc...

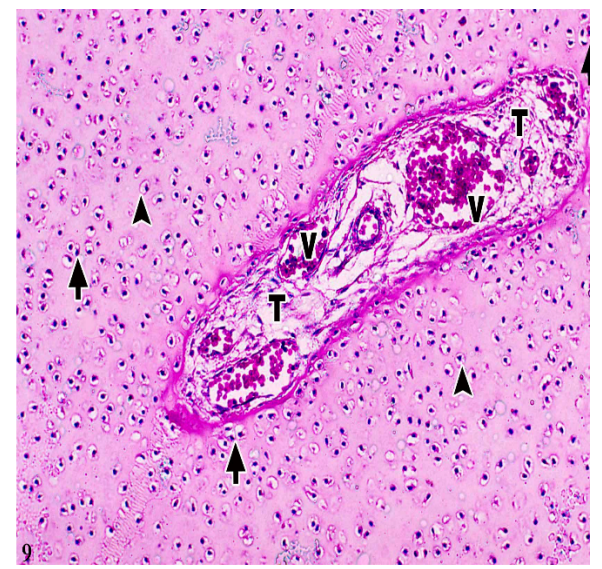

Fig. (9): A photomicrograph of a section in human fetal calcaneus aged 15 weeks revealing differentiation of most of the cells into chondrocytes (arrow heads) with appearchortion cartilage canal appears large in size with rounded by connective tissue $(T)$. (H\& E $x$ 100)

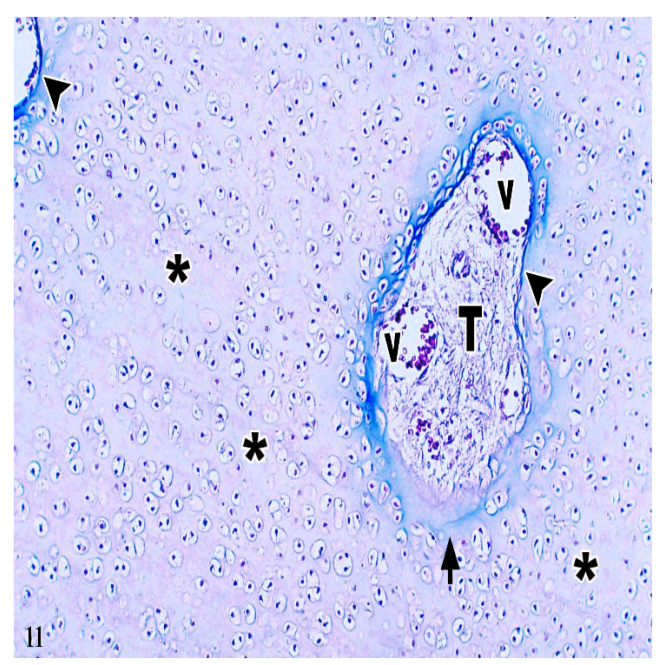

Fig. (11): A photomicrograph of a section in human etal calcaneus aged 15 weeks shon ing blue stained collagenous fibers in the wall of the cartilage canals (arrow heads), matrix around the canals (short arrows) and mesenchymal CT (T) around the blood vessels (V). Fine blue stained collagenous fibers are demonstrated in the matrix (asterisks) demonstrated in the matrix (asterisks) between the proliferating chondrocy-
tes. (Mallory's stain $x \quad 100$ )

Vol. 42, No. 1 \& 2 Jan. \& April, 2013

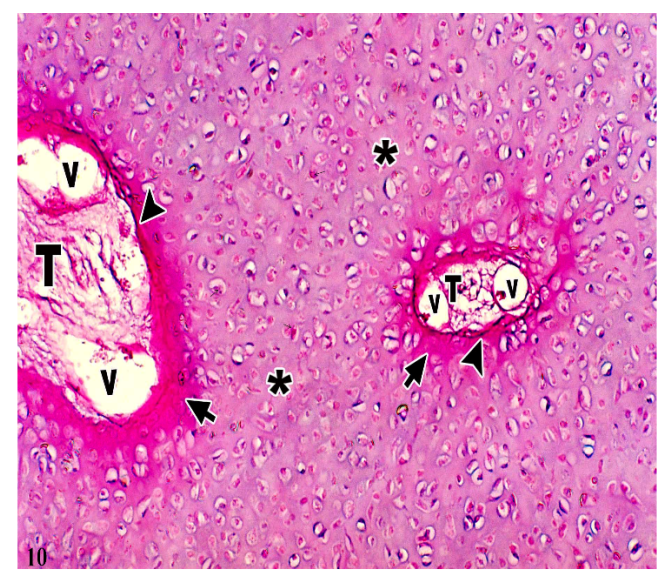

Fig. (10): A photomicrograph of a section in human fetal calcaneus aged 15 weeks showing a strong PAS positive reaction in the cytoplasm of chondrocytes (arrows), thick wall of the cartilage canals (arrow heads), matrix around the canals (shor arrow) and $(\mathrm{V})$. The matrix ( $\mathrm{T}$ ) around the liferating PAS positive reaction. (AB/PAS reaction $X 100$ )

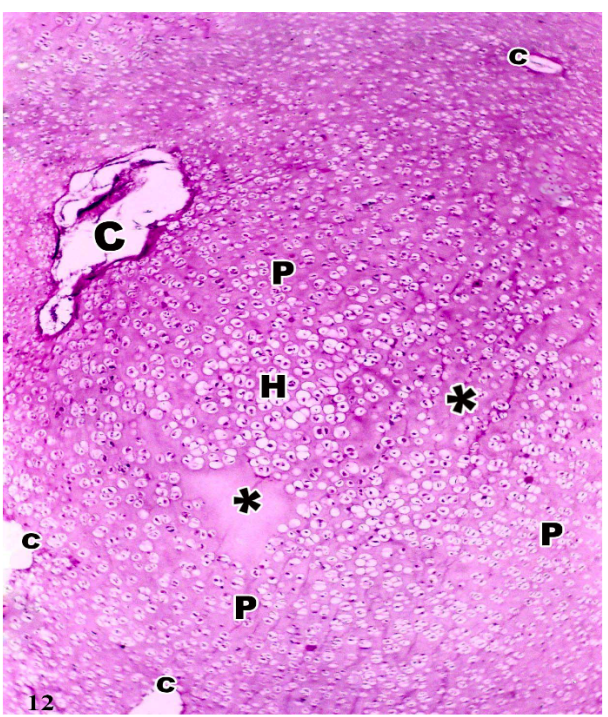

Fig. (12): A Photomicrograph of a section in fetal calcaneus aged 17 weeks showing the central part of the calcaneus containing proliferating chondrocytes $(P)$ arranged in pairs or small groups and hypertrophied chondrocytes $(H)$ separated by abundant matrix (asterisks). The cartilages canals (C) show little content and are concentrically arranged around the are concentrically arranged around the
central part of the calcaneus. (H\&E X40 


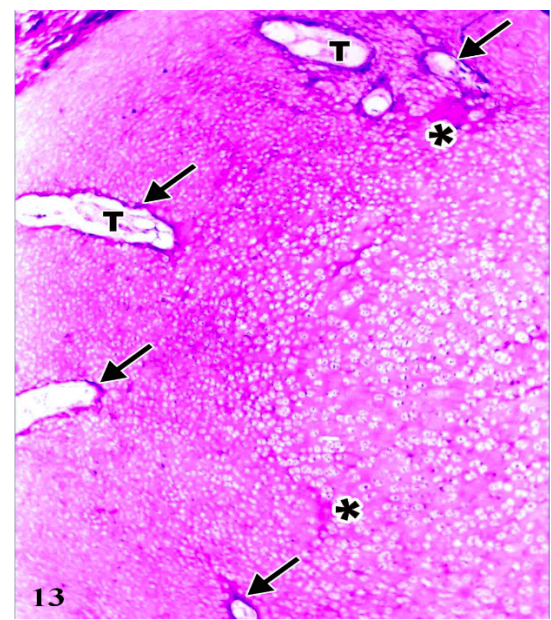

Fig. (13): A Photomicrograph of a section in fetal calcaneus aged 17 weeks showing PAS positive reaction in the matrix (asterisks), wall of the canals (arrows) and connective tissue content ( $T$ ) of the cartilage canals. (AB/PAS reaction $\times$ 400)

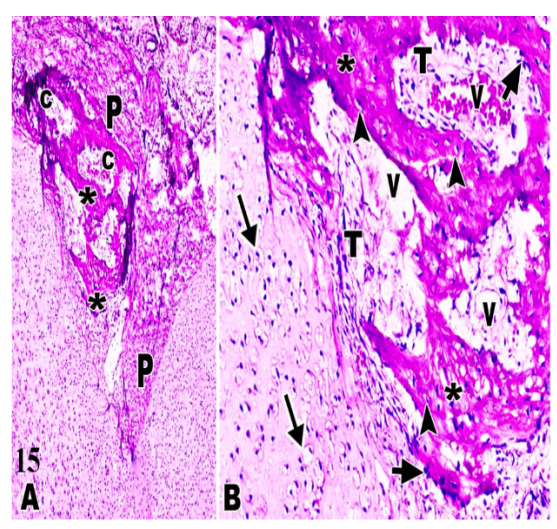

Fig. (15): Two photomicrographs of sections in fetal calcaneus aged 19 weeks stained
with H\&E:- (A): showing appearance of irregular perichondral plates (asteof irregular perichondral plates (aste-
risks) enclosing multiple canals (C) in risks) enclosing multiple canals (C) in high power magnification of the inset in (A) showing the perichondrial plates containing osteocytes (arrow heads) embedded in the matrix (asterisks) and osteoblasts (short arrows) on the peripheral borders. The canals contain blood vessels $(\mathrm{V})$ and connective tissue (T). The majority of the calcanean cells appear differentiated into chondrocytes (arrows). (100)

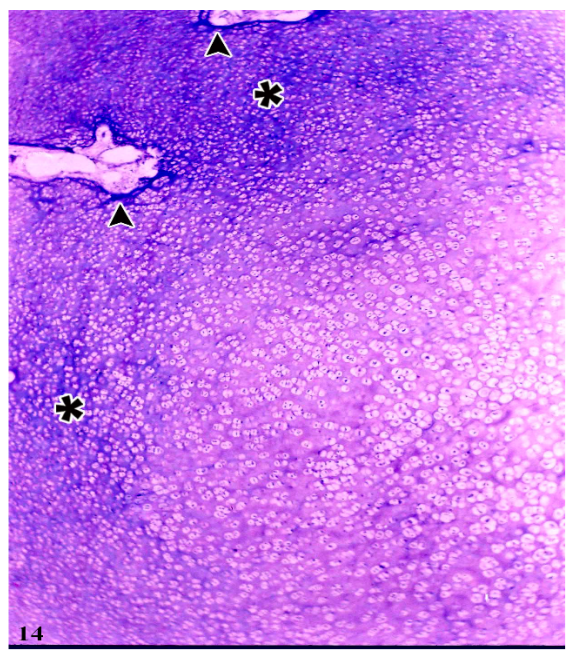

Fig. (14): A photomicrograph of a section in human fetal calcaneus aged 17 weeks showing blue stained collagenous fibers in the wall of the cartilage canals (arrow heads) and in the matrix (asterisks). (Mallory's stain $x$ 40)

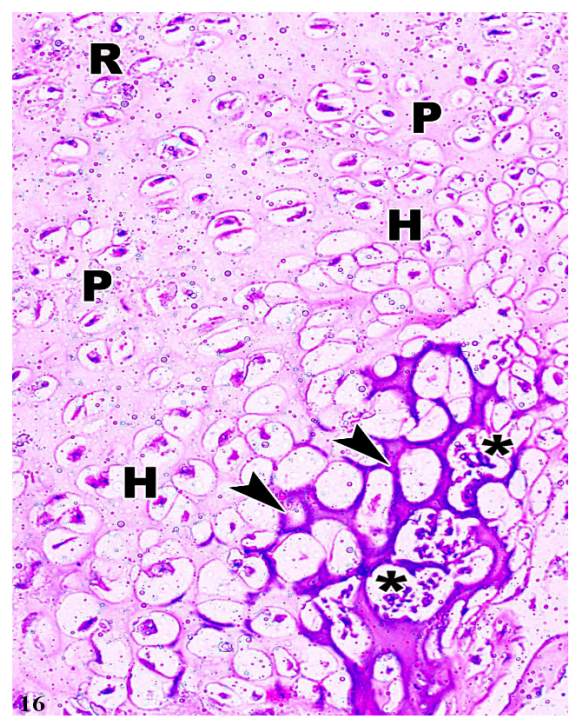

Fig. (16) : A photomicrograph of a section in fetal calcaneus aged 19 weeks showing the central part of the developing calcaneus comprising different zones; resting chondrocytes $(\mathrm{R})$, proliferating chondrocytes $(P)$ arranged in pairs or small groups, hypertrophied chondrocytes $(\mathrm{H})$ ated by calcified matrix (arrow heads) ated by calcifed matrix (arrow heads). senchymal tissue (asterisks). (H\&E X 400)

MANSOURA MEDICAL JOURNAL 
100 PRENATAL DEVELOPMENT OF HUMAN CALCANEUS etc...

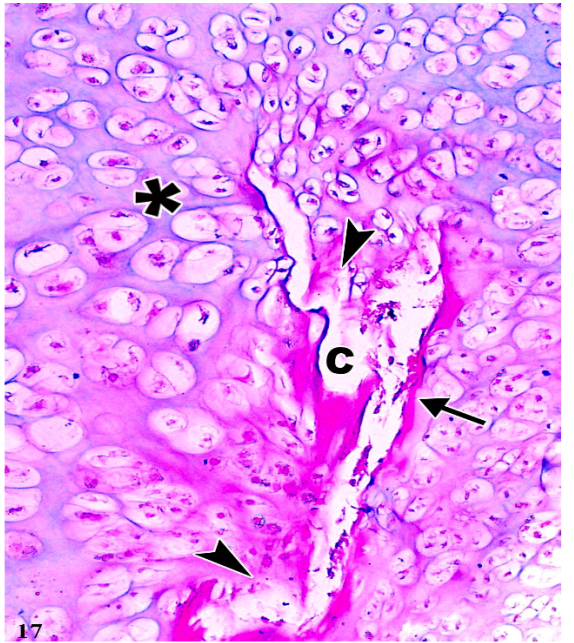

Fig. (17): A photomicrograph of a section in human fetal calcaneus aged 19 weeks showing a strong PAS positive reaction in certain parts of the wall (arrow) of the cartilage canals and the other parts appear interrupted (arrow heads). The matrix (asterisk) exhibits AB/PAS posmatrix
itive
$400)$

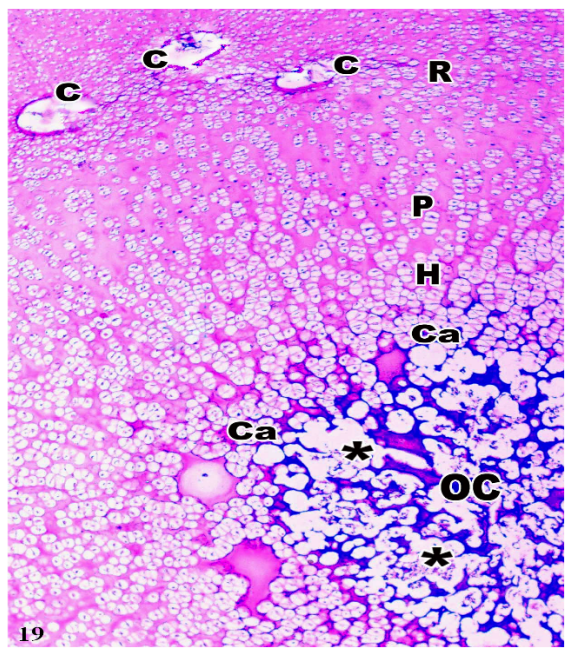

Fig. (19) : A photomicrograph of a section in human fetal calcaneus aged 22 weeks showing the developing endochondral ossification center zones; resting chondrocytes $(R)$, proliferatsmall groups, hypertrophied chondrocytes (H) and hypertrophied chondrocytes separated by calcified matrix (Ca). The majority
of the calcified channels are invaded by mesenchymal tissue (asterisks). Note the cartilaround the endochondral ossification center. (H\&E x 40)

Vol. 42, No. 1 \& 2 Jan. \& April, 2013

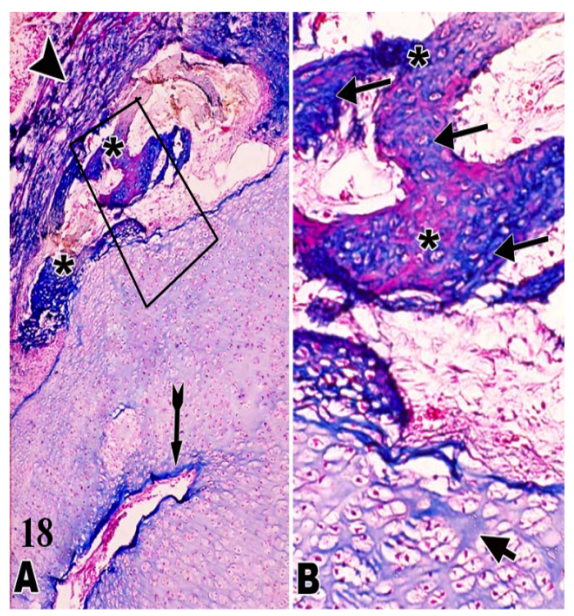

Fig. (18): Two photomicrographs of sections in human teta caicaheus aged 19 week

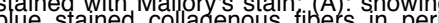
chondrium (head arrow), perichondra pe cartilage canals (tailed arrow). ( 400 B): A high power magnification the inse (A) showing blue stained collagenous tipers (arrows) in the matrix of the peristained collagenous fibers (short arrow in the matrix of the hyaline cartilage of

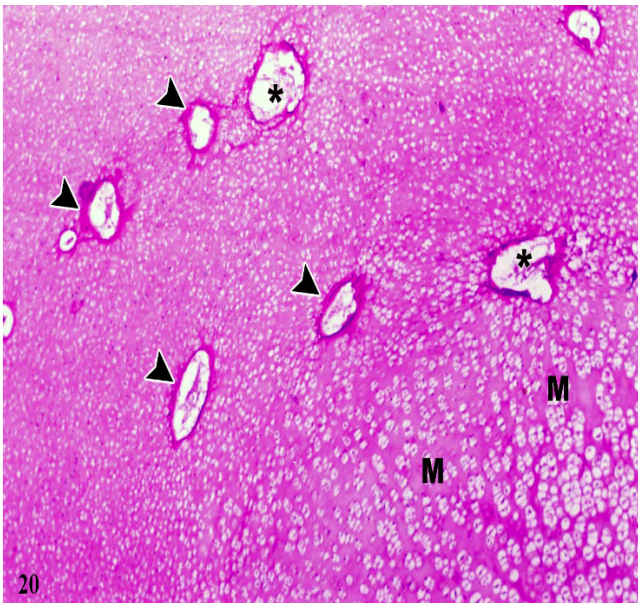

Fig. (20) : A photomicrograph of a section in human fetal calcaneus aged 22 weeks showing a strong PAS positive reaction in the thick wall of the cartilage canals (arrow heads), in the little CT content of the cartilage canals (asterisks) and in the matrix (M). (AB/PAS reaction $X$ 40) 


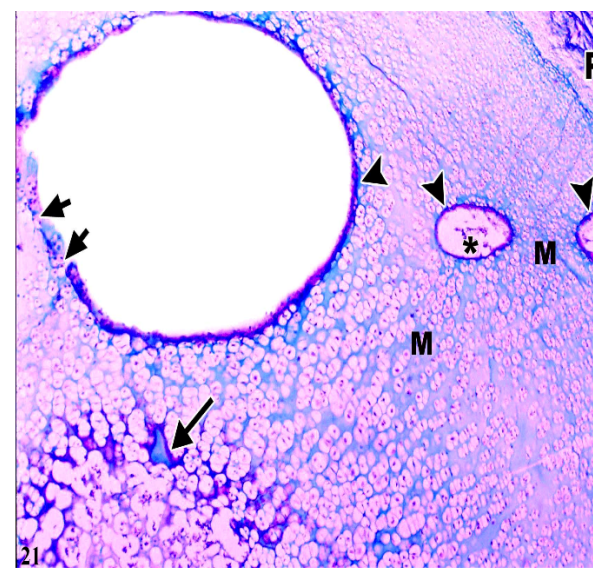

Fig. (21): A photomicrograph of a section in human fetal calcaneus aged 22 weeks showing blue stained collagenous fibers in the perichondrium $(P)$, wall of the cartilage canals, little CT content of the cartilage canals (asterisks) and calcified matrix (arrow). The matrix (M) between the chondrocytes stained pale blue. The large cartilage canal between the hypertrophied chondrocytes exhibits an interrupted wall (short arrows) and loss of content. (Mallory's stain $x$ 100)

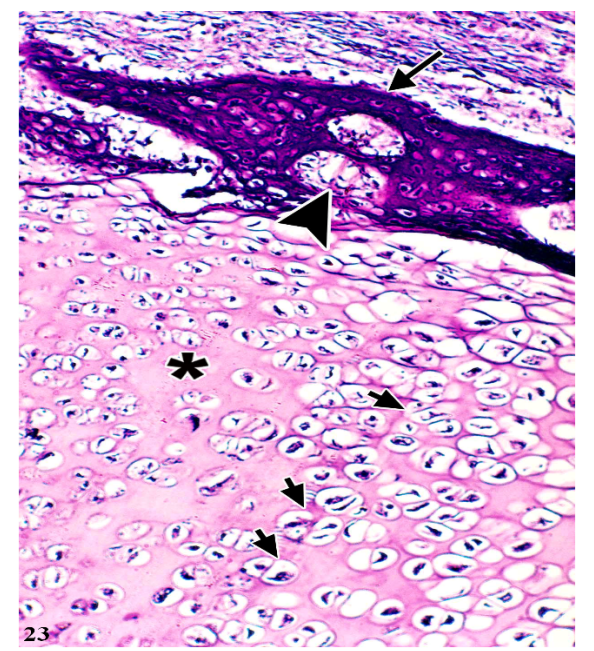

Fig. (23): A photomicrograph of a section in human fetal calcaneus aged 24 weeks showing regular perichondral plate around the regular perichondral plate around the nals (arrow head). Most of the cells unnals (arrow head). Most of the cells under the perichondrium appear differen-
tiated into mature chondrocytes (short tiated into mature chondrocytes (short
arrows) and separated by abundant maarrows) and separated by
trix (asterisk). (H\&E x100)

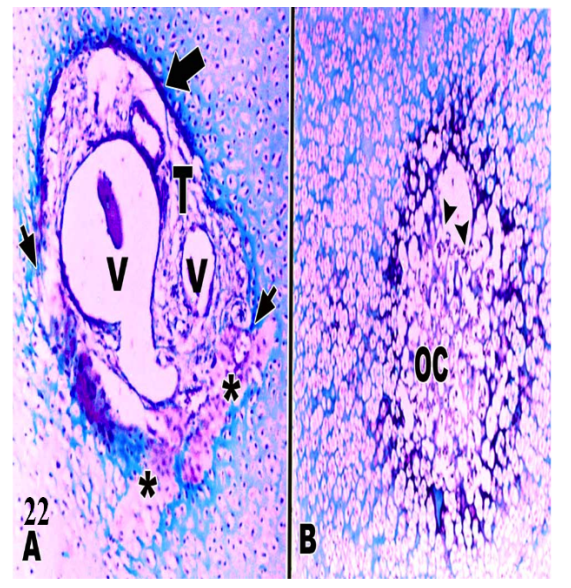

Fig. (22): Two photomicrograph of sections in human fetal cal-

(A): shows blue stained collagen fibers around the wall (thick arrow) of the cartilage canal and in the connective tissue (T) in-between the blood vessels (V). The
wall of the cartilage canal appears interrupted (shor arrows) with passage of its cellular content (asterisks) canal incorporated in the endochondral ossification municating with the surrounding channels. (Mallory's
muntain

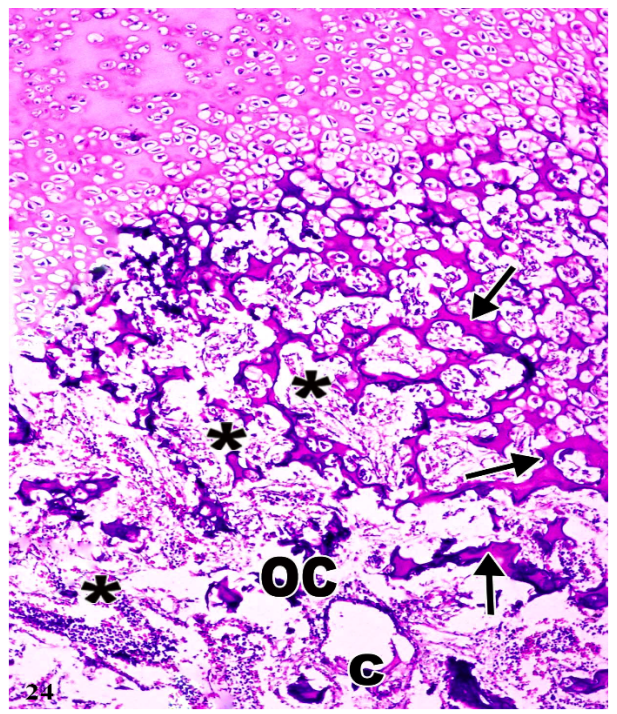

Fig. (24): A photomicrograph of a section in human etal calcaneus aged 24 weeks showing the appearance of multiple bony spicules (arrows) separated by multiple bone marrow spaces (asterisks) at the center of the developing endochondral ossification center (OC). A cartilage canal (C) with little content is seen at the ossification center (H\&E x 40).

MANSOURA MEDICAL JOURNAL 
102 PRENATAL DEVELOPMENT OF HUMAN CALCANEUS etc...

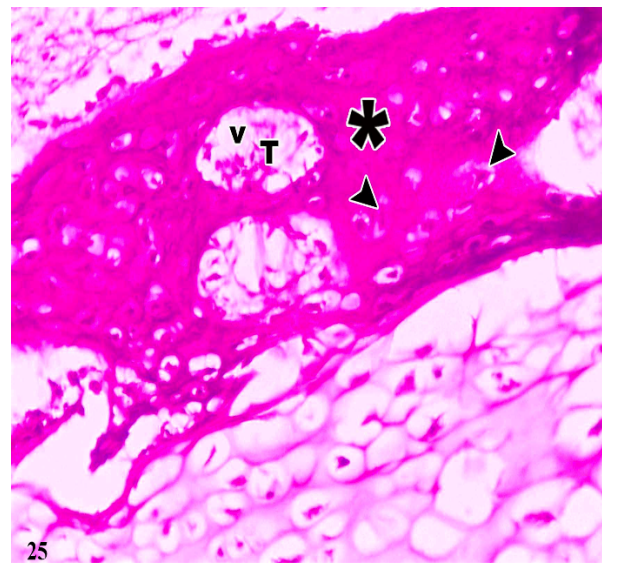

Fig. (25) : A photomicrograph of a section in human fetal calcaneus aged 24 weeks plate with a strong PAS positive reaction in the matrix (asterisk), cytoplasm of osteocytes (arrow heads) and in connective blood vessels $(V)$. (AB/PAS reaction $\mathrm{X}$ 400)

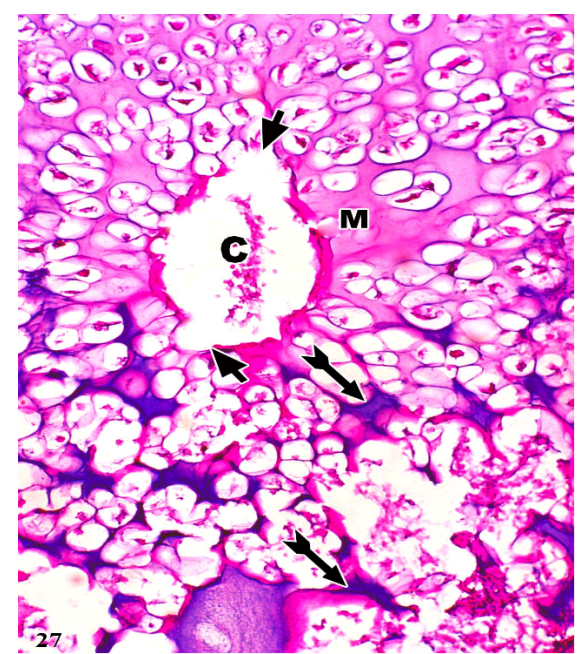

Fig. (27): A high power magnification of the inset in (Fig.26) showing a strong PAS positive reaction in the thin discontinuous wall (short arrows) of cartilage canals which open into the surrounding hywhich open into the surrounding hypertrophied chondrocytes and its little content $(C)$. The calcified matrix ap-
pears stained with alcian blue (tailed arrows). (AB/PAS reaction $X$ 400)

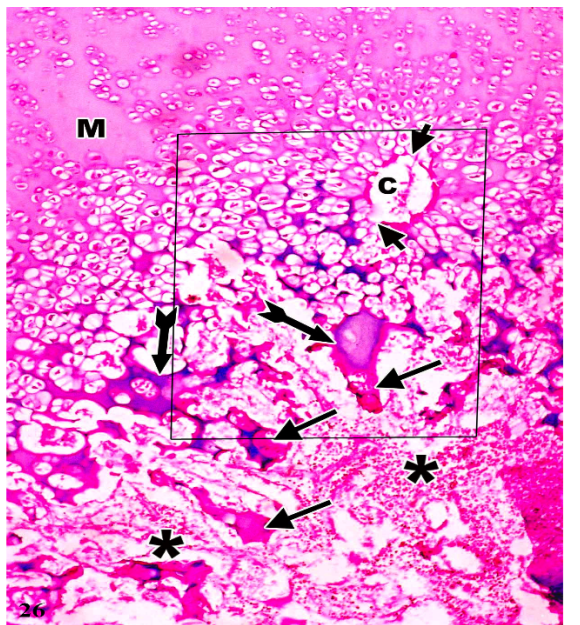

Fig. (26): A photomicrograph of a section in human fetal calcaneus aged 24 weeks showing a strong PAS positive reaction in the thin discontinuous wall (short arrows) of cartilage canals and its little content (C). A PAS positive reaction is also seen in the newly formed bony spicules (arrows) around the calcified matrix and in the toplasm of the bone marrow cells (aste-

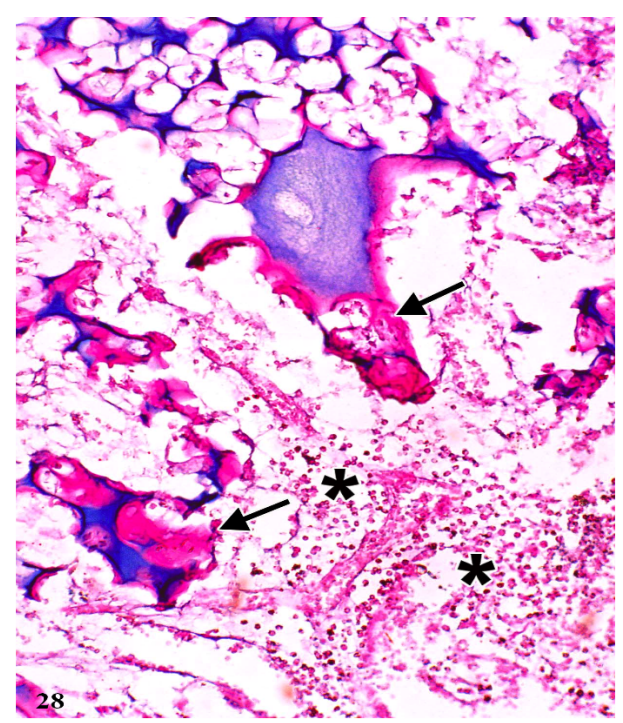

Fig. (28): A high power magnification of the inset in (Fig.26) showing a strong PAS positive reaction in the newly formed bony spicules (arrows) around the calcified matrix and in the cytoplasm of the bone marrow cells (asterisks). (AB/PAS reaction $\mathrm{X}$ 400)

Vol. 42, No. 1 \& 2 Jan. \& April, 2013 


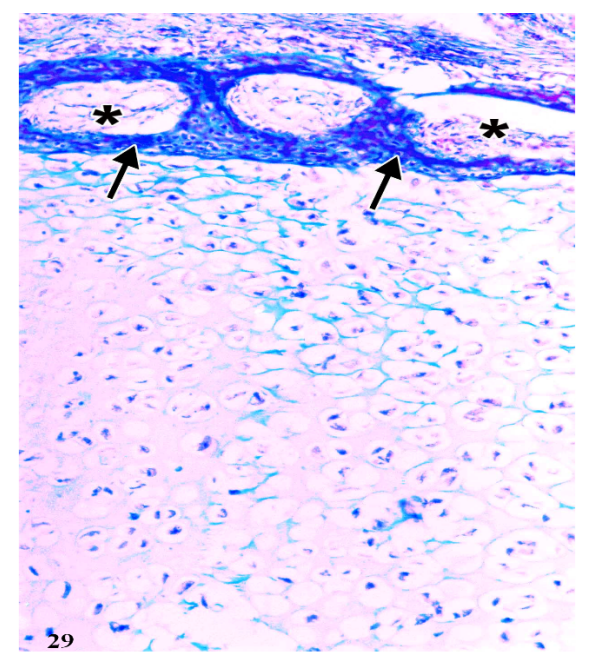

Fig. (29): A photomicrograph of a section in human fetal calcaneus aged 24 weeks showing blue stained collagenous fibers in the perichondral plate (arrows) and connective tissue content of the cartilage canals (asterisks). (Mallory's stain $\times 40$ )

\section{DISCUSSION}

The calcaneus is the largest tarsal bone which constitutes the heel. Many congenital and acquired disorders affect this bone [Kumar et al., 1991].23 Basically, endochondral bone development depends upon neovascularization, and the early generation of vascularized cartilage canals is an initial event, clearly preceding the formation of the secondary ossification centre (SOC) [Blumer et al., 2008B]. ${ }^{7}$ Therefore, the present study investigated the developing human fetal calcaneus and the relationship of the cartilage canals to

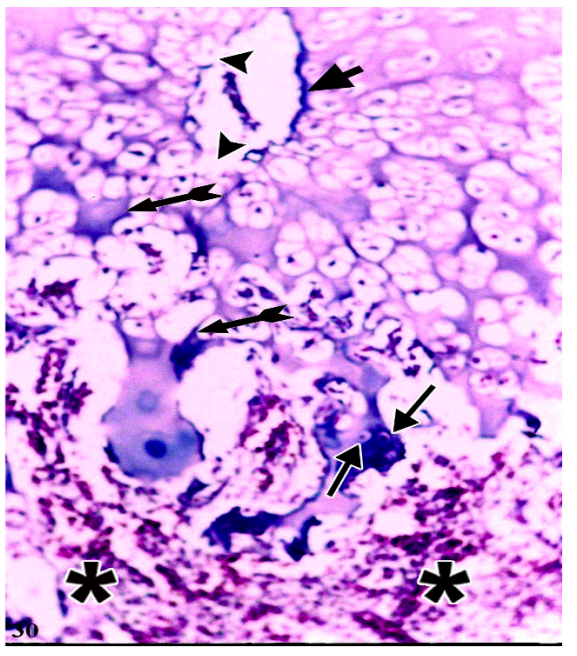

Fig. (30): A photomicrograph of human fetal calcaneus aged 24 weeks showing blue stained collagenous fibers around part of the thin (arrows) interrupted (arrow heads) wall of the cartilage canal which open into the sur rounding hypertrophied chondrocytes and calcified matrix (tailed arrows). The bone marrow cells (asterisks) stained red. Note resence of osteocytes (arrows) embedded in the newly formed bony spicules. (Mallory's stain x 40)

the stages of ossification and to clarify their function in the process of bone formation.

In $9^{\text {th }}$ week-aged human fetus, the calcaneus showed clumps of undifferentiated cells with mitotic figures. There were no evident cartilage canals. In $10^{\text {th }}$ week-aged human fetus, the cartilage canal originated from the perichondrium, invaded the calcaneus and gave many side sprouts in between undifferentiated cells inside the calcaneus. The early-developing cartilage canals contained multiple small blood ves- 
104 PRENATAL DEVELOPMENT OF HUMAN CALCANEUS etc...

sels and mesenchymal CT. At the $13^{\text {th }}$ week-aged fetus, the calcanean cells surrounding the cartilage canal appeared differentiated into large rounded chondrocytes with the presence of cell nests. The canals were small in size and few in number. They contained mesenchymal CT and were surrounded by an area of early proliferating chondrocytes.

It was reported that the cartilage canals are always present in the human fetal calcaneus from the $11^{\text {th }}$ week onward but ossification begins about the $13^{\text {th }}$ to $14^{\text {th }}$ week aged fetus [Agrawal et al., 1986]. ${ }^{1}$ In long bones, endochondral bone formation, the process by which most parts of the skeleton evolve, leads to the establishment of the diaphyseal primary ossification centre (POC) and epiphyseal secondary ossification centre (SOC).

An essential event for the development of the SOC is the early generation of vascularized cartilage canals that requires the proteolytic cleavage of the cartilaginous matrix. This, in turn, will allow the canals to grow into the epiphysis. The formation of the cartilage canals is promoted by tartrate-resistant acid phos- phatase (TRAP) and membrane type-1 matrix metalloproteinases (MT1-MMP), enzymes that can degrade all components of the extracellular matrix. In addition, TRAPpositive multinucleated chondroclasts resorb the calcified cartilage as well as MT1-MMP-positive osteoclasts resorb the mineralized bone matrix. It has been demonstrated that these enzymes (MMPs) are needed to allow the vessels and bone-forming cells access into the epiphysis contributing to the establishment of the canals and enabling their further advancement into the epiphysis by resorbed the cartilage matrix [Barksby et al., 2006\& Blumer et al., 2008A \& Takahara et al., 2004].4,6,29

In the current study, it was evident that from the $15^{\text {th }}$ week- aged fetus onward, most of the calcanean cells were differentiated into chondrocytes with appearance of cell nests. It has been proved that the differentiation of chondocytes is well regulated by both systemic factors and locally secreted factors, which act on receptors to affect intracellular signalling and activate chondrocyteselective transcription factors. Systemic factors that regulate the be- 
havior of chondrocytes in growth of cartilage include growth hormone and thyroid hormone [Mackie et al., 2008]. ${ }^{24}$ In addition, the local secreted factors in the cartilage extracellular matrix include, bone morphogenetic proteins (BMPs) and Sry-box 9 (SOX9), which play important roles in the process of mesenchymal condensations, promote chondrocyte differentiation and proliferation. Moreover, parathyroid hormone related peptide (PTHrP) and Indian hedgehog (Ihh) modulate the rate of cartilage differentiation through the formation of a negative feedback loop. Furthermore, fibroblast growth factor receptor 3 (FGFR3) inhibits chondrocytes proliferation and enhances their differentiation into the hypertrophic phenotype [Kitoh and Ishiguro, 2007\& Mackie et al., 2008].22,24

In the present study, in the $17^{\text {th }}$ week-aged human fetus, the calcaneus showed the developing endochondral ossification center having hypertrophied chondrocytes surrounded by basophilic matrix. The cartilage canals showed little content and were concentrically arranged around the central part of the calcaneus. These findings were against the theory of ischemic necrosis held by other authors who stated that ischemia may precipitate the hypertrophy of chondrocytes during endochondral ossification [Trueta, 1968]. ${ }^{31}$ On the other hand, the present results are in agreement with other workers who stated that endochondral ossification occurs in areas rich in cartilage canals [Agrawal et al., 1984\& Agrawal et al., 1986]. 2, 1

It was proved that the vascular endothelial growth factor (VEGF) produced by hypertrophied chondrocytes may play a key role in the regulation of vascular invasion of the growth plate [Horner et al., 1999].21 It was found that many diseases especially related to hip joint may occur as a result of impaired vascular supply. During bone growth, development, and remodeling, angiogenesis as well as osteogenesis are closely associated processes, sharing some essential mediators [Zhang et al., 2009]. 33 VEGF is initially recognized as the best-characterized endothelial-specific growth factor, which increases vascular permeability and angiogenesis, It plays a role during endochondral ossification by stimulation of blood vessel invasion into hypertrophic cartilage resulting in its replacement by trabecular bone [Mayr 
106 PRENATAL DEVELOPMENT OF HUMAN CALCANEUS etc...

et al., 2002].26 VEGF also has a matrix and osteoblasts on the periphfunctional role for recruitment of os- eral borders. The canals contained teoprogenitor cells in the course of blood vessels and abundant CT. The endochondral bone formation or re- majority of the calcanean cells under modeling [Fiedler et al., 2005]. ${ }^{11}$

In addition, VEGF-A secreted by human adult mesenchymal stem cells seen to be elevated during osteogenesis promotes sprouting of endothelial cells demonstrating its a paracrine role in blood vessel formation. It also acts as osteoblast chemoattractive and proliferative autocrine factor and plays an essential role in osteoblast differentiation [Mayer et al., 2005]. 25 The factors regulating chondrocyte proliferation and hypertrophy include the Sox trio, PTH related peptide, Indian hedgehog, the runt-related transcription factor family, fibroblast growth factor receptor 3 and bone morphogenetic protein and other factors including hypoxiainducible factor 1alpha and VEGF [Higashikawa et al., 2006]. ${ }^{19}$

In the $19^{\text {th }}$ week, the calcaneus displayed appearance of irregular perichondral plates enclosing multiple canals in the perichondrium, most probably perichondral ossification center. The perichondral plates contained osteocytes embedded in the perichondrium were differentiated into chondrocytes. In addition, the central part of the developing calcaneus exhibited different concentric zones as; resting chondrocytes, proliferating chondrocytes that arranged in pairs or small groups, hypertrophied chondrocytes and hypertrophied chondrocytes separated by calcified matrix. Some channels became invaded by mesenchymal tissue. This finding is in agreement with other researchers who reported that, the human calcaneus is frequently ossified from two centers, an inconstant perichondral center at inferolateral part of the bone and a constant principal endochondral center which appeared in the central region of the calcaneus [Agrawal et al., 1986]. ${ }^{1}$

It has been reported that the cartilage canals are regularly arranged in shells surrounding the ossification center. Whereas most of the shell canals might be involved in the nourishment of the cartilage, the inner shell is directly connected with the perichondral ossification groove of 
Ranvier and with large vessels from outside. In this way the inner shell canal imports extracellular matrix, cells and vessels into the cartilage. With the so-called communicating canals it is also connected to the endochondral ossification center to which it delivers extracellular matrix, cells and vessels [Helga et al., 2001]. ${ }^{18}$

In the $22^{\text {nd }}$ week aged the human fetal calcaneus, the majority of the calcified channels in the central part of the developing endochondral ossification center were invaded by mesenchymal tissue. It can be explained by the findings of [Mackie et al., 2008] ${ }^{24}$ who reported that, during endochondral ossification, chondrocytes proliferate, undergo hypertrophy and terminally the hypertrophied chondrocytes undergo apoptosis and are replaced by bone; the cartilage extracellular matrix is then invaded by blood vessels, osteoclasts, bone marrow cells and also osteoblasts which deposit bone on remnants of cartilage matrix.

In the $24^{\text {th }}$ week, the calcaneus showed regular perichondral plate around the calcaneus enclosing cartilage canals. Most of the cells un- der the perichondrium were differentiated into mature chondrocytes and separated by abundant matrix. Multiple bony trabeculae of spongy bone separated by multiple bone marrow spaces were demonstrated in the developing endochondral ossification center. A cartilage canals with little content were seen incorporated at the ossification center.

It has been reported that during endochondral bone formation, vascular invasion initiates the replacement of avascular cartilage by bone. Once the perichondrium is vascularized, osteoclast precursors are recruited from the circulation and the induction of matrix metalloproteinases-9 and matrix metalloproteinases13 can be observed in parallel with the activation of TGF-beta signaling. Perichondral angiogenesis is a prerequisite for subsequent cartilage vascularization and is differentially regulated by VEGF-A isoforms [Takimoto et al., 2009] $]^{30}$.

Previous histological and radiological investigations of 16 fetuses (32 feet) and newborns, ranging in age from 15 to 44 weeks, revealed two types of ossification; endochondral ossification through primary os-

MANSOURA MEDICAL JOURNAL 
108 PRENATAL DEVELOPMENT OF HUMAN CALCANEUS etc...

sification center and intramembraneous ossification through periosteal bone formation (PBF), were found to coexist in both calcaneus and talus. In addition, Ranvier's grooves (RG), or perichondral ossification grooves were observed as shallow, saucerlike or semicircular structures. As with PBFs, there are three and two $R G$ in the calcaneus and talus, respectively. Perichondral ossification groove appears in time order and is located regularly in the concave areas of the adult calcaneus. The findings support the hypothesis that one function of periosteal bone formation (Ranvier's grooves) is to limit the growth of the calcaneus. Thus, they are responsible for the irregular contour of the calcaneus [Cheng et al., 1995]. ${ }^{9}$

Other workers reported that, the cartilage canals with their vascular structures are included in the endochondral center and also at perichondral center that indicate the positive role of the vascular structures of the periosteum and its extension inside the cartilage in the form of cartilage canals [Agrawal et al., 1986]. ${ }^{1}$ It was reported that, the presence of communicating cartilage canals is necessary for the transport of nutri- ents, deliver stem cells as well as vessels into the extracellular matrix and ossification center for the initiation of ossification [Blumer et al., 2005\& Helga et al., 2001].8,18 On the other hand, within the clubfoot calcaneus, the coordination of perichondral and endochondral ossification is disturbed, ossification grooves and associated cartilage canals are not found in regular positions, and the process of endochondral ossification obviously is disturbed. The findings in the clubfoot specimens point to grave irregularities of the extracellular matrix within or outside the calcaneus [Fritsch and Eggers, 1999]. ${ }^{13}$ It has been proved that the fetal calcanean ossification center was ultrasonically detectable in $24^{\text {th }}$ week of gestation as eggshaped echo-rich area [Gentili et al., 1984]. ${ }^{14}$

The present study recorded a highly significant increase in the mean number and diameter of cartilage canals with increasing of fetal age. In the 15th week aged fetus, the AB/PAS and Mallory's stained calcaneus sections displayed a strong positive reaction in the thick wall of the cartilage canals, matrix around the canals and mesenchymal 
CT around the blood vessels. On the other hand, in the $22^{\text {nd }}$ and $24^{\text {th }}$ weeks aged fetuses, the cartilage canals were surrounded by thin interrupted wall which open into the surrounding hypertrophied chondrocytes or calcified channels. In addition, cartilage canals with little content were seen incorporated at the ossification center.

In the developing chicken femur, two types of canals have been distinguishable: shell canals and communicating canals. Shell canals were present in the reserve zone and were arranged in successive layers. Communicating canals spring from the shell canals and passed down into the proliferative zone and into the hypertrophic zone. These canals were conical shaped and were orientated nearly in parallel to the long axis of the femur. Cartilage canals comprise venules, arterioles, capillaries (mature and immature), and undifferentiated mesenchymal cells [Blumer et al., 2004]. 5 In addition, the canals contain chondroclasts, which open the lacunae of hypertrophic chondrocytes, and this is followed by invasion of mesenchymal cells into the empty lacunae and formation of an osteoid layer. In older stages this layer is mineralized and increased in thickness by addition of further cells. Outside the SOC cartilage canals are surrounded by osteoid, which is formed by the process of perichondral bone formation. Therefore the cartilage canals are contributed to both perichondral and endochondral bone formation and the osteoblasts have the same origin in both processes [Blumer et al., 2005]. ${ }^{8}$

Vascular endothelial growth factor (VEGF) plays an important role during endochondral bone formation in hypertrophic cartilage remodeling. VEGF is immunolocalized intracellularly in the hypertrophic chondrocytes of the growth plate, in the chondrocytes around cartilage canals of the epiphysis and in endothelial cells of the vessels. The normal hyaline cartilage is negative, resting zone and the proliferative zone of the growth plate are VEGF-negative, suggesting that the known angiogenetic peptide VEGF plays a role in process of endochondral ossification [Blumer et al., 2004 \&Petersen et al., 2002].5,28

Overall, there was AB/PAS posiMANSOURA MEDICAL JOURNAL 
110 PRENATAL DEVELOPMENT OF HUMAN CALCANEUS etc...

tive reaction in the cartilage matrix in-between the differentiated, proliferated and hypertrophied chondrocytes in all groups of the present study with intense alcian blue staining of the calcified matrix within the growth plate region at 24 weeks aged fetus. PAS positive reaction was also seen in the newly formed bony spicules around the calcified matrix and in the Matrix of the perichondral plates. Similar results are recorded by other authors in normal calcaneus and it has been suggested that the chondrocytes are highly active in producing new extracellular proteoglycans [Gilbert et al., 2001]. ${ }^{15}$

In endochondral bone formation the non-resorbed cartilage struts provide a scaffold onto which osteoblasts start to deposit osteoid (nonmineralized type I collagen). Osteoblasts further differentiate into osteocytes as soon as they are completely embedded into the mineralized bone matrix but this transformation process is still not fully understood [Franz et al., 2006]. ${ }^{12}$ On the other hand, in congenital talipes equinovarus deformities of calcaneus, the cartilage matrix contains fewer chondrocytes which are smaller and flatter and less differentiated.
Cartilage canals decrease in number and are stained pale with alcian blue, suggesting that the amount of extracellular proteoglycans is reduced. Therefore the coordination of perichondral and endochondral ossification is retarded as well as the cartilage spicules are rare resulting in formation of a small hypoplastic bone and, subsequently, a smaller foot. [Fritsch and Eggers, 1999\& Gilbert et al., 2001]. ${ }^{13,} 15$

In the $10^{\text {th }}$ week-aged fetal calcaneus, the cartilage canal appeared originated from the perichondrium, invaded the calcaneus and gave many side sprouts inside the calcaneus. In the $13^{\text {th }}$ week-aged fetal calcaneus onward, the Mallory's stained sections showed blue stained collagenous fibers in wall of the cartilage canals with mesenchymal CT inside the cartilage canal. In addition blue stained collagenous fibers were seen in the matrix between the proliferating chondrocytes and in the perichondral plate. These results can be explained by other immunohistochemical study of the developing chicken femur which reported that the cartilage canal matrix contains type I collagen, few type II collagen fibrils and proteoglycans are lacking. 
In contrast, in the cartilage matrix type II collagen and proteoglycans are abundant but no type I collagen is found. Communicating canals are surrounded by a distinct layer of type I collagen indicating that osteoid tissue is formed around these canals. Hypertrophic chondrocytes label for type I collagen and it seems possible that chondrocytes adjacent to the communicating canals differentiate into bone-forming cells [Blumer et al., 2004]. 5

\section{Conclusions}

The present work demonstrates that both endochondral and perichondral ossification processes started to appears in the $19^{\text {th }}$ week aged human fetal calcaneus and became more developed in the 24th week aged fetus. In addition, the present results have provided evidence that cartilage canals are extensions from the perichondral blood vessels. They comprise blood vessels and undifferentiated mesenchymal cells and are involved in nourishment of the cartilage as well as in the both ossification process (endochondral and perichondral bone formation). The calcaneal endochondral ossification center was detectable at 22nd, 24th weeks of gestation so, it could be a useful mean to evaluate gestational age in late pregnancy by ultrasonography.

\section{REFERENCES}

1. Agrawal D. , kulkarni D. and Atre P. (1986) : The participation of cartilage canals in the ossification of the human fetal calcaneus. J, Anat., 147, pp135-142.

2. Agrawal, P., Atre, P., and Kulkarni, D. (1984) : The role of the cartilage canals in the ossification of the talus. Acta Anatomica. 119, 238240.

3. Bancroft JD. and Gamble M. (2008) : Theory and Practice of Histological Techniques, 6th ed. Churchill Livingstone Elsevier. China. PP:121-127 and PP: 173-174.

4. Barksby HE., Milner JM., Patterson AM., Peake NJ., Hui W., Robson T., Lakey R., Middleton J., Cawston TE., Richards CD. and Rowan AD. 2006 : Matrix metalloproteinase 10 proMANSOURA MEDICAL JOURNAL 
PRENATAL DEVELOPMENT OF HUMAN CALCANEUS etc...

motion of collagenolysis via procollagenase activation: implications for cartilage degradation in arthritis. Arthritis Rheum. 54(10):32443253.

5. Blumer MJ., Longato S. and Fritsch H. (2004) : Cartilage canals in the chicken embryo are involved in the process of endochondral bone formation within the epiphyseal growth plate. Anat Rec A Discov Mol Cell Evol Biol. 279 (1):692-700.

6. Blumer MJ., Longato S. and Fritsch H. (2008 A) : Localization of tartrateresistant acid phosphatase (TRAP), membrane type-1 matrix metalloproteinases (MT1-MMP) and macrophages during early endochondral bone formation. J Anat. 213(4):431-441.

7. Blumer MJ., Longato S. and Fritsch H. (2008B) : Structure, formation and role of cartilage canals in the developing bone. Ann Anat. 190(4):305-315.

Vol. 42, No. 1 \& 2 Jan. \& April, 2013
8. Blumer MJ., Longato S., Richter E., Perez MT., Konakci KZ. and Fritsch H. (2005) : The role of cartilage canals in endochondral and perichondral bone formation: are there similarities between these two processes? J Anat; 206 (4):359-372.

9. Cheng X., Wang Y., Qu H and Jiang Y. (1995) : Ossification processes and perichondral ossification groove of Ranvier: a morphological study in developing human calcaneus and talus. Foot Ankle Int. 16(1):7-10.

10. Doschak MR., Cooper DM., Huculak CN., Matyas JR., Hart DA., Hallgrimsson B., Zernicke RF. and Bray RC. (2003) : Angiogenesis in the distal femoral chondroepiphysis of the rabbit during development of the secondary centre of ossification. J Anat. 203(2):223233.

11. Fiedler J., Leucht F., Walten- 
berger J., Dehio C. and Brenner RE. (2005) : VEGF-A and PIGF-1 stimulate chemotactic migration of human mesenchymal progenitor cells. Biochem Biophys Res Commun. 26;334(2):561-568.

12. Franz-Odendaal TA, Hall BK. and Witten PE. (2006) : Buried alive: how osteoblasts become osteocytes. Dev Dyn. 235(1):176-190.

13. Fritsch $H$. and Eggers $R$. (1999) : Ossification of the calcaneus in the normal fetal foot and in clubfoot. $J$ Pediatr Orthop. JanFeb;19(1):22-26.

14. Gentili P., Trasimeni A. and Giorlandino C. (1984) : Fetal ossification centers as predictors of gestational age in normal and abnormal pregnancies. J Ultrasound Med. May;3(5):193197.

15. Gilbert JA., Roach HI. and Clarke NM. (2001) : Histological abnormalities of the calcaneum in congenital talipes equinovarus. J Orthop Sci. 6(6):519-526.

16. Gruber HE., Lachman RS. and Rimoin DL. (1990) : Quantitative histology of cartilage vascular canals in the human rib. Findings in normal neonates and children and in achondrogenesis II-hypochondrogenesis. J Anat.; 173: 69-75.

17. Hall RL. and Shereff MJ. (1993) : Anatomy of the calcaneus. Clin Orthop Relat Res., (290):27-35.

18. Helga Fritsch, Erich Brenner and Paul Debbage. (2001) : Ossification in the human calcaneus: a model for spatial bone development and ossification. Journal of Anatomy. 199, pp 609 616.

19. Higashikawa A., Kawaguchi H., Nakamura K. and Chung U. (2006) : Interactions of chondrocytes and osteoblasts during endochondral bone formation].

MANSOURA MEDICAL JOURNAL 
Clin Calcium. 16(5):829836.

20. Hootnick DR., Levinsohn EM., Crider RJ. and Packard DS. (1982) : Congenital arterial malformations associated with clubfoot. A report of two cases. Clin Orthop Relat Res., (167):160-163.

21. Horner A., Bishop N., Bord S., and Beeton C. (1999) : Immunolocalization of vascular endothelial growth factor (VEGF) in human neonatal growth plate cartilage. Journal of Anatomy. 194, 519- 524.

22. Kitoh $H$. and Ishiguro $\mathbf{N}$. (2007) : Molecular mechanism in the differentiation of chondrocytes. Clin Calcium., 17(4):493-498.

23. Kumar R., Matasar K., Stansberry S., Shirkhoda A., David R., Madewell JE. and Swischuck LE. (1991) : The calcaneus: normal and abnormal. Radiographics., $11(3): 415-440$.

24. Mackie EJ., Ahmed YA., TaVol. 42, No. 1 \& 2 Jan. \& April, 2013 tarczuch L., Chen KS.

and Mirams M. (2008) :

Endochondral ossification: how cartilage is converted into bone in the developing skeleton. Int $\mathrm{J}$ Biochem Cell Biol., 40(1):46-62.

25. Mayer H., Bertram H., Lindenmaier W., Korff T., Weber H. and Weich H. (2005) : Vascular endothelial growth factor (VEGF-A) expression in human mesenchymal stem cells: autocrine and paracrine role on osteoblastic and endothelial differentiation. $\mathrm{J}$ Cell Biochem. 1;95(4):827-839.

26. Mayr-Wohlfart U., Waltenberger J., Hausser H., Kessler S., Günther KP., Dehio C., Puhl W. and Brenner RE. (2002) : Vascular endothelial growth factor stimulates chemotactic migration of primary human osteoblasts. Bone. 30 (3):472-477.

27. Moore K. (1982) : The Developing Human Clinically Oriented Embryology, 3rd 
Edition. W.B. Saunders

Company, Philadelphia, London, Tokyo. P:78, 95.

28. Petersen W., Tsokos M. and Pufe T. (2002) : Expression of VEGF121 and VEGF165 in hypertrophic chondrocytes of the human growth plate and epiphyseal cartilage. J Anat. 201 (2):153-157.

29. Takahara M., Naruse T., Takagi M., Orui H. and Ogino T., (2004) : Matrix metalloproteinase-9 expression, tartrate-resistant acid phosphatase activity, and DNA fragmentation in vascular and cellular invasion into cartilage preceding primary endochondral ossification in long bones. J Orthop Res. 22(5):1050-1057.

30. Takimoto A., Nishizaki Y., Hi- raki $Y$. and Shukunami $C$. (2009) : Differential actions of VEGF-A isoforms on perichondrial angiogenesis during endochondral bone formation. Dev Biol. 15; 332(2):196-211.

31. Trueta J., (1968) : Studies on the development and decay of the human frame. W.B.Saunders, Philadelphia: pp79-83.

32. Walling AK. (2008) : The adult clubfoot (congenital pes cavus). Foot Ankle Clin., 13 (2):307-14, vii.

33. Zhang HF., Zhang SY. and Liu JM. (2009) : Effect of point injection of red-sageroot on the hip joint function in ischemic femoral head necrosis patients. Zhen Ci Yan Jiu. 34(1):5760. 


\title{
الملحص العربى
}

\section{تطور النمو الجنينى لعظمة العقب البشرى و دورقنوات الغضروف فى عملية التعظم: دراسة هستولوجية}

\author{
أمـل محمــلد مصطفى* و أمانى محمد شمس \\ قسمى الأنسجة وبيولوجيا الخليةًّ* والتشريح وعلم الأجنة \\ كليّة الطبّ. جامعة المنصورة \\ المحلدمح : إن عظمة العقب تبين بشكل واضح خصائص عمليـات التعظم التي تحدث فى كل من العظام \\ القصيرة و الطويلة حيث توجد قنوات الغضروف فى كردوس العظام الطويلـة و فى العظام القصيرة و غير \\ المنتظمة و لكن دورها فى عملية التعظم للم يثبت . \\ هلف البحث : دراسـة هستولوجيـة لتطورالنـمو الجـيـى لعظمـة العقب البشـري و إيضـاح دور قنوات \\ الغضروف في عملية تشكيل العظام. \\ المواد و الطلرق \& اجـرى هـذا البحث على أربعـة وعشرين جــينـا بشـريا فى الأسـابيع التاسع و العـاشر و \\ الثالث عشـرو الخـامس عشـرو السـابع عشـرو التـاسـع عشر و الثانى و العشـرين و الرابع و العشـرين من \\ الحمل (ثلاثة أجنـة لكل عمـر) حيث أخذت قطاعـات متسـلسلـة من عظمـة العقب و تم معالجتهـا بصبغة \\ الهيماتوكسلين و الايوسين وصبغة الالشيان الازرق و شيف الحمضية و صبغة مالورى . \\ النتقائح \& أظهرت عظمة العقب تواجد خلايـا غير ممـيزة و بلدون قنوات الغضـروف عند الأسبوع التاسـع \\ مـن الحمل كما بـأت تنشئـة القنوات الغضروفية مـن السمحاق الخارجى عند الأسبوع العاشرو عند الأسبوع \\ الثالث عشر وجـدت مـنطقة بدايـة تكاثر خلايـا الغضـروف التى رتبت في مجمـوعات و قد اشتمـلت قنوات \\ الغضروف علي نسيج ضـام و أوعيـة دمـوية وأحيطت بـألياف الكولاجـين و أظهرت قنوات الغضروف تفاعلا \\ ايجـابيا لصبغـة شـيف الحمضـيـة فضلا عن ظهور أليـاف كولاجين سـميكة حسول القنـوات الغضـروفية فى \\ القطاعات المصبوغة بصبغة مالورى.
}

Vol. 42, No. 1 \& 2 Jan. \& April, 2013 
و عند الأسبوع الخامس عشـر ظهرت خلايا غضروفية متضخمـة ومـرتبة في مجمـوعات صغيرة كما زادت هذه الخلايا الغضروفية المتضخمة أيضا في المركز الرئيسي للتعظم وكانت مرتبة فى أزواج أو فى مجمموعات صغيـرة و مـحاطة بهـناطق مـتسعـة ذات قاعدية شـاحبـة و ذلك عند الأسبـوع السـابع عشرو عنــ الأسبوع التاسع عشر ظهر مركز التعظم السمحاقى الخارجى .

و قـد أظهرت الدراسة أيضا وجود مركز التعظم الغضروفى الداخلى في صورة مـادة متعظمـة ذات فراغات نخاعية حول قناة الغضروف إضافة إلى ازدياد مساحة مادة النسيج القاعدية حول الغضروف المتعظم و ذلك عند الأسبوع الثانى و العشرين من الحمل و عنــ الأسبـوع الرابع و العشـرين من الحمل ازداد تطور كل من: مـركز السمـحاق الخارجى و مـركز الغضروف الداخلى للتعظم حيث اظهر المركز الرئيسى للتعظم منطقة كبيرة من التشكيل العظمى فى صورة أشوالك و حواجز فصلت بمناطق من النخاع مملوءة بخلايا دموية كما

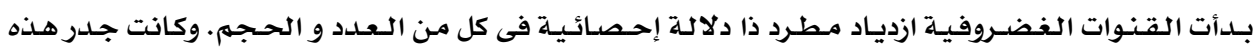
القنوات رقيقة متقطعة و ذات محتوى اقل مع تقدم الحمل.

الهلاوصح \& إن قنوات الغضـروف تشـارك فى تغـذية خلايـا الغضـروف و كذلك فى عملية التعظم كما أن مـركز التعظم الغضروفى الداخلى فى عظمة العقب البشرية يظهر مـا بين الأسبوعين الثانى و العشرين إلى الرابع و العشرين من الحمل مما يعد وسيلة مفيدة لتقييم عمر الحمل 